\title{
Characterization of a Novel Alginate Lyase from Marine Bacterium Vibrio furnissii $\mathrm{H1}$
}

\author{
Xiaoyan Zhu ${ }^{1,2, *}$, Xiangqian Li ${ }^{1,2}$, Hao Shi ${ }^{1,2}$, Jia Zhou ${ }^{1,2}$, Zhongbiao Tan ${ }^{1,2}$, Mengdi Yuan ${ }^{2}$, \\ Peng Yao ${ }^{2}$ and Xiaoyan Liu ${ }^{3}$ \\ 1 Jiangsu Provincial Engineering Laboratory for Biomass Conversion and Process Integration, \\ Huaiyin Institute of Technology, Huaian 223003, China; lixq@hyit.edu.cn (X.L.); \\ ilyshihao@163.com (H.S.); jiazhou@hyit.edu.cn (J.Z.); tanzb@hyit.edu.cn (Z.T.) \\ 2 School of Life Science and Food Engineering, Huaiyin Institute of Technology, Huaian 223003, China; \\ 15996162102@163.com (M.Y.); yaopeng0224@163.com (P.Y.) \\ 3 Jiangsu Key Laboratory for Biomass-based Energy and Enzyme Technology, Huaiyin Normal University, \\ Huaian 223300, China; catty5082003@163.com \\ * Correspondence: zhuxy@hyit.edu.cn; Tel./Fax: +86-517-8359-1190
}

Received: 6 December 2017; Accepted: 11 January 2018; Published: 15 January 2018

\begin{abstract}
Alginate lyases show great potential for industrial and medicinal applications, especially as an attractive biocatalyst for the production of oligosaccharides with special bioactivities. A novel alginate lyase, AlyH1, from the marine bacterium Vibrio furnissii $\mathrm{H} 1$, which has been newly isolated from rotten seaweed, was purified and characterized. The purified enzyme showed the specific activity of $2.40 \mathrm{U} / \mathrm{mg}$. Its molecular mass was $35.8 \mathrm{kDa}$. The optimal temperature and $\mathrm{pH}$ were $40{ }^{\circ} \mathrm{C}$ and $\mathrm{pH} 7.5$, respectively. AlyH1 maintained stability at neutral $\mathrm{pH}(7.0-8.0)$ and temperatures below $30{ }^{\circ} \mathrm{C}$. Metal ions $\mathrm{Na}^{+}, \mathrm{Mg}^{2+}$, and $\mathrm{K}^{+}$increased the activity of the enzyme. With sodium alginate as the substrate, the $K \mathrm{~m}$ and $V \max$ values of AlyH1 were $2.28 \mathrm{mg} / \mathrm{mL}$ and $2.81 \mathrm{U} / \mathrm{mg}$, respectively. AlyH1 exhibited activities towards both polyguluronate and polymannuronate, and preferentially degraded polyguluronate. Products prepared from sodium alginate by $\mathrm{AlyH} 1$ were displayed to be di-, tri-, and tetra-alginate oligosaccharides. A partial amino acid sequence (190 aa) of AlyH1 analysis suggested that $\mathrm{AlyH} 1$ was an alginate lyase of polysaccharide lyase family 7 . The sequence showed less than $77 \%$ identity to the reported alginate lyases. These data demonstrated that AlyH1 could be as a novel and potential candidate in application of alginate oligosaccharides production with low polymerization degrees.
\end{abstract}

Keywords: alginate lyase; Vibrio furnissi; purification; characterization; oligosaccharides; polysaccharide lyase family 7

\section{Introduction}

Alginate is a major component in the cell walls of marine macroalgae, which are available in large amounts in marine environments and are one of the fastest growing organisms in the world [1]. It is a linear acidic polysaccharide consisting of 1,4-linked $\beta$-D-mannuronate and $\alpha$-L-guluronate residues, arranged in varying sequences with uniform regions of mannuronate (poly-M) or guluronate (poly-G), or a mixture of mannuronate and guluronate (poly-MG) [2,3].

Alginate can be depolymerized into alginate oligosaccharides. Compared with corresponding chemical and physical methods, enzymatic depolymerization has certain advantages, including high production yields and the production of specific oligosaccharides [4]. Alginate lyase degrades alginate via the $\beta$-elimination mechanism, producing various oligosaccharides with unsaturated uronic acid at the non-reducing terminus and unsaturated uronic acid monomers [5]. Based on the substrate specificities, alginate lyases are classified into mannuronate lyase (EC 4.2.2.3) and 
guluronate lyase (EC 4.2.2.11) that preferentially break up the M- and G- rich alginates, respectively [1]. Some alginate lyases show bifunctional activity for both poly-M and poly-G [6,7]. Alginate lyases are also characterized by their structure, termed as polysaccharide lyase (PL) families. On the basis of alginate lyase primary structures, alginate lyases are organized into seven PL families including PL5, PL6, PL7, PL14, PL15, PL17, and PL18 [2,8]. Alginate lyases have attracted increasing attention in recent years due to their critical role in the biotransformation of alginate into high-value and functional oligosaccharides that exhibit a variety of biological activities such as antitumor [9], non-specific immunostimulatory [10], and antioxidant activity [11], as well as root growth-promoting activity towards plants [12]. Alginate lyases also play an important role in the elucidation of alginate fine structures [13], the protoplast preparation of red and brown algae [14], and the treatment of cystic fibrosis [15], as well as biofuel production [3].

Various alginate lyase-producing organisms, including bacteria, fungi, brown algae, marine mollusks, and viruses, have been explored and the enzyme characterization investigated [5,16]. In this study, we report on a new alginate lyase-producing bacterium; the alginate lyase, AlyH1, was purified and its enzymatic properties were investigated, and its partial amino acid sequence was determined.

\section{Results and Discussion}

\subsection{Isolation of Alginate-Degrading Microorganism}

A large number of alginates are annually produced by algae in the sea. Various alginate lyases produced by marine microorganisms are actively involved in marine alginate degradation. Utilizing sodium alginate as the sole carbon source, this work isolated several microbial strains based on the appearance of the clearing hydrolytic zone and alginate lyase activities from the fermentation culture. The strain with the most remarkable activity was selected and designated as $\mathrm{H} 1$ for further studies. A $1475 \mathrm{bp}$ fragment of the 16S rRNA gene of the strain H1 (Genbank accession number: MG214325) was cloned and sequenced. The alignment results revealed that $16 \mathrm{~S}$ rRNA gene sequences of strain H1 was 100\% identical to the sequence of Vibrio furnissii NCTC 11218 chromosome 1 (CP002377.1) and 99\% identical to the 16S rRNA gene sequence of $V$. furnissii JCM 1282 (LC050179). According to the blast result and phylogenetic position of its 16S rRNA (Figure S1), H1 was assigned to the genus $V$. furnissii and designated as $V$. furnissii H1. Several papers had previously reported that the Vibrio sp. could produce alginate lyase (Table 1). To the best of our knowledge, this study is the first to report on alginate lyase derived from $V$. furnissii.

Table 1. Characterization of alginate lyases from different Vibro sp. microorganisms.

\begin{tabular}{|c|c|c|c|c|}
\hline Microorganisms & Molecular Mass (kDa) & Optimal pH/Temperature $\left({ }^{\circ} \mathrm{C}\right)$ & Substrate Specificity & Reference \\
\hline V. furnissii $\mathrm{H} 1$ & 35.8 & $7.5 / 40$ & Poly-M, poly-G & This study \\
\hline Vibrio sp. SY08 & 33 & $7.6 / 40$ & Poly-M, poly-G & [17] \\
\hline Vibrio sp. QD-5 & 62 & $8.9 / 35$ & poly-G & [18] \\
\hline Vibrio sp. NJU-03 & 48.12 & $7.0 / 30$ & Poly-M, poly-G & [19] \\
\hline Vibrio sp. W13 & 54.12 & $8.0 / 30$ & Poly-M, poly-G & [20] \\
\hline \multirow[t]{7}{*}{ V. splendidus $12 \mathrm{~B} 01$} & 68.2 & $8.5 / 25$ & Poly-M, poly-G & [21] \\
\hline & 59.0 & $7.5 / 20-25$ & Poly-M, poly-G & [21] \\
\hline & 36.5 & $8.0 / 20$ & Poly-M, poly-G & [21] \\
\hline & 35.2 & $7.5 / 25$ & Poly-M, poly-G & [21] \\
\hline & 80 & $6.5 / 16$ & Poly-M, poly-G & [22] \\
\hline & 83 & $7.0 / 30$ & Poly-M, poly-G & [22] \\
\hline & 81 & $7.5 / 35$ & Poly-M & [22] \\
\hline Vibrio sp. JAM-A9m & 28 & 7.6 and $9 / 30$ & Poly-M & [23] \\
\hline Vibrio sp. QY105 & 37 & $7.0 / 38$ & Poly-M, poly-G & [24] \\
\hline Vibrio sp. YKW-34 & 60.0 & $7.0 / 40$ & Poly-M, poly-G & [25] \\
\hline Vibrio sp.YWA & 62.5 & $7.0 / 25$ & Poly-M, poly-G & [26] \\
\hline \multirow[t]{2}{*}{ Vibrio sp. O2 } & 28.4 & - & Poly-M & [27] \\
\hline & 25.2 & - & Poly-M & [27] \\
\hline Vibrio sp. 510-64 & 34.6 & $7.5 / 35$ & Poly-G & [28] \\
\hline Vibrio sp. QY101 & 34 & $7.5 / 40$ & Poly-M, poly-G & [29] \\
\hline \multirow[t]{2}{*}{ Vibrio sp. AL-9 } & 25 & $9.0 /-$ & Poly-G & [30] \\
\hline & 31 & $8.0 /-$ & Poly-M & [30] \\
\hline V. harveyi AL-128 & - & $7.8 /-$ & Poly-G & {$[31]$} \\
\hline
\end{tabular}




\subsection{Purification of AlyH1}

AlyH1 was purified by ammonium sulphate fractionation and two-step column chromatographic procedures with a final yield of $9.28 \%$ (Table 2). An approximately 18.46 -fold purification was obtained with a specific activity of $2.40 \mathrm{U} / \mathrm{mg}$ for purified AlyH1. The purified enzyme showed a single band on sodium dodecyl sulfatepolyacrylamide gel electrophoresis (SDS-PAGE) and the molecular weight of the enzyme was estimated to be $35.8 \mathrm{kDa}$ (Figure 1).

Table 2. Purification of AlyH1.

\begin{tabular}{cccccc}
\hline Purification Steps & Total Protein (mg) & Specific Activity (U/mg) & Total Activity (U) & Yield (\%) & Purification (Fold) \\
\hline Liquid supernatant & 121.84 & 0.13 & 15.84 & 100.00 & 1.00 \\
\hline$\left(\mathrm{NH}_{4}\right)_{2} \mathrm{SO}_{4}$ fractionation & 79.53 & 0.16 & 12.72 & 80.33 & 1.23 \\
\hline $\begin{array}{c}\text { Q-Sepharose } \\
\text { chromatography }\end{array}$ & 6.67 & 0.82 & 5.47 & 34.53 & 9.31 \\
\hline $\begin{array}{c}\text { Gel filtration } \\
\text { chromatography }\end{array}$ & 0.61 & 2.40 & 1.47 & 18.46 \\
\hline
\end{tabular}

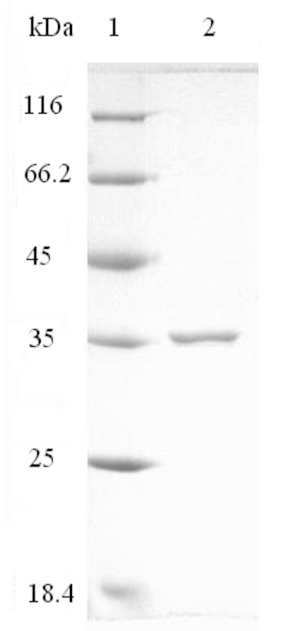

Figure 1. SDS-PAGE of AlyH1 (lane 2). The marker proteins (lane 1) are commercially-obtained standards as described.

\subsection{Characterization of AlyH1}

\subsubsection{Effects of Temperature and $\mathrm{pH}$ on AlyH1 Activity and Stability}

Optimal temperature of the alginate lyases from marine bacteria differed significantly. The optimal temperatures of the alginate lyases from Vibrio sp. were $16-40{ }^{\circ} \mathrm{C}$ (Table 1). As shown in Figure 2a, AlyH1 had maximum activity at $40{ }^{\circ} \mathrm{C}$, which was higher than most other alginate lyases from Vibrio sp. AlyH1 exhibited an excellent stability below $30^{\circ} \mathrm{C}$. More than $60 \%$ of residual activity was still maintained after incubation at $40{ }^{\circ} \mathrm{C}$ for $30 \mathrm{~min}$. Zhu et al. recently reported an alginate lyase (AlgNJU-03) from Vibrio sp. NJU-03 possessed approximately $40 \%$ activity after incubation at $40{ }^{\circ} \mathrm{C}$ for $30 \mathrm{~min}$ [19]. The optimal $\mathrm{pH}$ of the enzyme was found to be 7.5 (Figure 2b). The optimal pHs for most alginate lyases from marine bacteria are between 7.0 and 8.5, and AlyH1 corresponded with this range. After incubation for $12 \mathrm{~h}$, AlyH1 retained more than $60 \%$ activity in a $\mathrm{pH}$ range of 6.5 to 8.5 and $80 \%$ activity in a pH range of 7.0 to 8.0 . The best stability appeared at $\mathrm{pH} 7.5$ (Figure $2 \mathrm{~b}$ ). Thus, the neutral $\mathrm{pH}$ condition was proven to be suitable for AlyH1 to conduct catalysis reaction and maintain activity. 


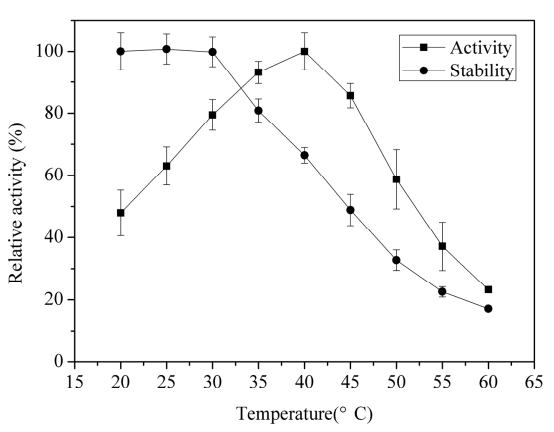

(a)

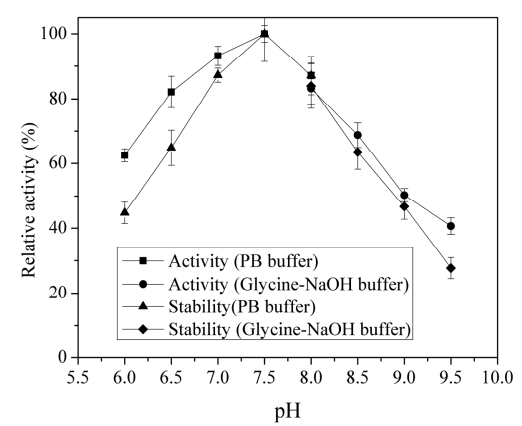

(b)

Figure 2. Effects of temperature and $\mathrm{pH}$ on the activity and stability of AlyH1. (a) Temperature profiles. The effect of temperature on AlyH1 activity was measured at different temperatures $\left(20-60{ }^{\circ} \mathrm{C}\right)$ in $50 \mathrm{mM}$ sodium phosphate buffer (PB, pH 7.5); the activity at $40{ }^{\circ} \mathrm{C}$ was taken as $100 \%$. Thermal stability of AlyH1 was determined at $40{ }^{\circ} \mathrm{C}$ in $50 \mathrm{mM}$ PB buffer ( $\mathrm{pH}$ 7.5) after the purified enzyme solution was incubated at different temperatures for $30 \mathrm{~min}$; the residual activity at $20{ }^{\circ} \mathrm{C}$ was taken as $100 \%$. (b) pH profiles. The activity was measured at $40^{\circ} \mathrm{C}$ in $\mathrm{PB}$ buffer ( $\mathrm{pH}$ 6.0-8.0) and glycine- $\mathrm{NaOH}$ buffer ( $\mathrm{pH}$ 8.0-9.5); the activity at $\mathrm{pH} 7.5$ was taken as $100 \%$. The $\mathrm{pH}$ stability was determined at $40{ }^{\circ} \mathrm{C}$ in $50 \mathrm{mM} \mathrm{PB}$ buffer ( $\mathrm{pH}$ 7.5) after the purified enzyme solution was incubated at $4^{\circ} \mathrm{C}$ in $\mathrm{PB}$ buffer ( $\mathrm{pH}$ 6.0-8.0) and glycine-NaOH buffer ( $\mathrm{pH} 8.0-9.5$ ) for $12 \mathrm{~h}$; the residual activity at $7.5^{\circ} \mathrm{C}$ was taken as $100 \%$.

\subsubsection{Effects of $\mathrm{NaCl}$ Concentration and Metal Ions on AlyH1 Activity}

As the alginate lyase was from a marine bacterium, the effect of $\mathrm{NaCl}$ in different concentrations $(0-0.6 \mathrm{M})$ on the activity of AlyH1 was investigated. AlyH1, showing the highest activity in the presence of $0.3 \mathrm{M} \mathrm{NaCl}$, had around $23 \%$ more activity than the control without the addition of $\mathrm{NaCl}$ (Figure S2a). This indicated that $\mathrm{NaCl}$ acted as a strong activator for this alginate lyase. A similar phenomenon was observed with the alginate lyase from Vibrio sp. strains such as Vibrio sp. QY105, Vibrio sp. YKW-34 and Vibrio sp. SY08, but the optimal concentration of $\mathrm{NaCl}$ was different from each other $[17,24,25]$. Little enzymatic activity of alginate lyase (AlyV5) from Vibrio sp. QY105 was detected without $\mathrm{NaCl}$ and the highest activity was observed in the presence of $0.5 \mathrm{M} \mathrm{NaCl}$ [24], while the activity of alginate lyase from Vibrio sp. YKW-34 was completely lost by dialysis and restored by addition of $\mathrm{NaCl}$, and the optimal activity exhibited in $0.1 \mathrm{M} \mathrm{NaCl}$ [25]. However, the alginate lyase from Vibrio sp. SY08, the enzyme was active in absence of $\mathrm{NaCl}$ and the highest activity was observed in the presence of $\mathrm{NaCl}$ less than $0.1 \mathrm{M}$ [17].

The effects of metal ions on AlyH1 activity were investigated by using various metal ions (Figure S2b). The enzyme activity was inhibited by $\mathrm{Zn}^{2+}, \mathrm{Fe}^{2+}, \mathrm{Cu}^{2+}, \mathrm{Mn}^{2+}$, and $\mathrm{Ag}^{+}$. However, $\mathrm{K}^{+}$and $\mathrm{Mg}^{2+}$ displayed activating effects among the metal ions investigated. $\mathrm{Mg}^{2+}$ showed the most stimulating effect with $119.25 \%$ of relative activity followed by $\mathrm{K}^{+}$with $110.31 \%$. The importance of $\mathrm{Mg}^{2+}$ and $\mathrm{K}^{+}$for some alginate lyases from marine bacteria such as I. halotolerans CGMCC 5336 [6] and Cobetia sp. WG-007 [32], has also been reported.

\subsubsection{Kinetic Parameters}

The Lineweaver-Burke graph demonstrated that the $\mathrm{Km}$ and $V$ max values of AlyH1 using sodium alginate as the substrate were $2.28 \mathrm{mg} / \mathrm{mL}$ and $2.81 \mathrm{U} / \mathrm{mg}$, respectively. The $\mathrm{Km}$ value of alginate lyase from Cobetia sp. WG-007 [32] and Vibrio sp. YWA [26], however, was 2.80 and $72.73 \mathrm{mg} / \mathrm{mL}$ toward sodium alginate, respectively. These values suggest that AlyH1 had a high affinity and catalytic efficiency for the sodium alginate substrate. 


\subsubsection{Substrate Specificity}

The substrate specificity of AlyH1 was characterized. The results showed that AlyH1 was active in degrading both poly-M and poly- $\mathrm{G}$, indicating that it is a bifunctional alginate lyase. The relative activities of sodium alginate, poly- $\mathrm{G}$ and poly-M were $100.00 \pm 5.76 \%, 128.37 \pm 4.35 \%$, and $52.14 \pm 3.52 \%$, respectively. It preferred poly-G over poly-M. Alginate lyases from different organisms showed differences in specific activity. The alginate lyases found in Pseudoalteromonas sp. SM0524 [33], Aspergillus oryzae [34], and Vibrio sp. YKW-34 [25] preferred to hydrolyze poly-M rather than poly-G, and alginate lyase from Agarivorans sp. JAM-A1m [35] and Vibrio sp.NJU-03 [19] preferred to degrade poly-G rather than poly-M, while some alginate lyases only showed the activity towards poly-G or poly-M $[18,23]$.

\subsubsection{Thin-Layer Chromatography Analysis of the Degradation Products}

The degradation products of the sodium alginate by AlyH1 were analysed by thin-layer chromatography (TLC). The results on the TLC plates clearly indicated that di-, tri-, and tetra-alginate oligosaccharides were generated (Figure 3). Different kinds of oligosaccharides were released by alginate lyases. The alginate lyase from Vibrio sp. W13 and Microbulbifer sp. 6532A produced oligosaccharides with degrees of polymerization of 2-6 [20,36]. The commercial enzyme originated from Flavobacterium sp. degraded alginate into penta- to hepta-oligosaccharides [37]. It indicated that AlyH1 may be a good tool for preparation of lower molecular weight alginate products than the commercial enzyme.

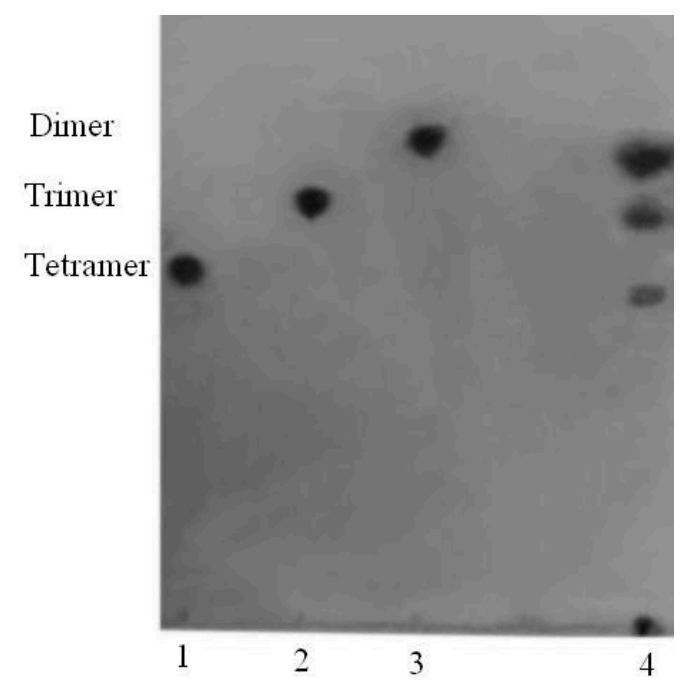

Figure 3. TLC analysis of the degradation products of sodium alginate. A $1 \mathrm{~mL}$ reaction mixture containing $1.0 \%$ sodium alginate was incubated at $30^{\circ} \mathrm{C}$ for $24 \mathrm{~h}$. The reaction products were separated on a TLC plate with 1-butanol: acetic acid: water $(3: 2: 2, v / v)$ and visualized with $10 \%(v / v)$ sulphuric acid in ethanol. Lane 1: tetramer; Lane 2: trimer; Lane 3: dimer; Lane 4: degraded sodium alginate (1.0\%).

\subsubsection{Determination of Partial Amino Acid Sequences of AlyH1}

An internal peptide sequence KDNVMHLTFKK of AlyH1 was determined. The sequence was blasted at the National Centre for Biotechnology Information databases (NCBI) database. It was completely identical to PL 7 family protein from Vibrio sp. CA-1004 (WP_086981048.1) and 90\% identical to PL 7 family protein from V. rumoiensis (WP_017024406.1).

To obtain more information from AlyH1, degenerate polymerase chain reaction (PCR) was carried out. AlyH1 mainly hydrolysed poly-G and the identified peptide showed high identity to a PL 7 family protein. It was speculated that AlyH1 was a PL7 alginate lyase. PL7 alginate lyase contain three highly conserved regions, I R(S/N) ELR(E/A/V) (M/T/Q), II Q (I/V) H, III YFKAG(N/L/A/V) 
Y [38]. Therefore, degenerate primers Valg1 and Valg2 were designed corresponding to conserved regions I and II. With the degenerate PCR, the partial nucleotide sequence (570 bp) of alyH1 (AlyH1 gene) was identified (Figure S3). The sequence was blasted in NCBI, and results showed that this nucleotide sequence displayed the highest identity of $67 \%$ to Agarivorans sp. L11 alkaline alginate lyase (KM018274.1) with the BLAST algorithm of discontiguous megablast or blastn, while no significant similarity was found with the BLAST algorithm of megablast. It means that the identified partial sequence of alyH1 had the low homology to the reported nucleotide sequence of alginate lyases. Efforts are underway to obtain complete sequence of alyH1.

The deduced amino acid sequence (190 aa) contained the sequence of KDNVMHLTFKK, which has been determined. The sequence was most homologous to the PL family 7 protein of Vibrio sp. CA-1004 (WP_086981048.1) with 76\% identity, followed by the PL family 7 protein of $V$. litoralis (WP_027695256.1) with 75\% identity, and the alginate lyase of $V$. rumoiensis (OEF27383.1) with 74\% identity, indicating AlyH1 was a PL7 alginate lyase. Some PL7 alginate lyases from Vibrio sp., which had different substrate specificity, were selected and a sequence homology blast was performed with the identified partial amino acid sequence of AlyH1. Three highly-conserved regions R(S/N) ELR, Q(I/V) $\mathrm{H}$, and YFKAG(N/V/L) Y were identified in Figure 4. Zhu et al. investigated the relationship between substrate specificity and protein sequence, and found that the poly-M-specific and poly-G-specific alginate lyases contain QVH and QIH in the conserved regions, respectively, [5]. Indeed, alginate lyases, such as AlgNJU-03 of Vibrio sp.NJU-03 [19] and AlyVI of Vibrio sp. QY101 [29], are known to preferably degrade poly-G, possessing QIH regions (Figure 4). Alginate lyase such as A9mT of Vibrio sp. JAM-A9m [23], AlyVOA and AlyVOB of Vibrio sp. O2 [27], favourably degraded poly-M, possessing QVH regions (Figure 4). AlyH1, containing the conserved region QIH, preferred poly-G as the substrate. The result was consistent with the reported alginate lyases. The identities of the partial amino acid sequence of AlyH1 to the corresponding partial amino acid sequence of alginate lyase from Vibrio sp.NJU-03 (ASA33933.1), Vibrio sp. QY101 (AAP45155.1), Vibrio sp. JAM-A9m (BAH79131.1), and Vibrio sp. O2 (ABB36771.1, ABB36772.1) were 36.36\%, 21.88\%, 35.32\%, 17.28\%, and 20.00\%, respectively. Based on its relatively low sequence identities and the distinguished enzymatic properties, it might be concluded that AlyH1 was a novel enzyme.

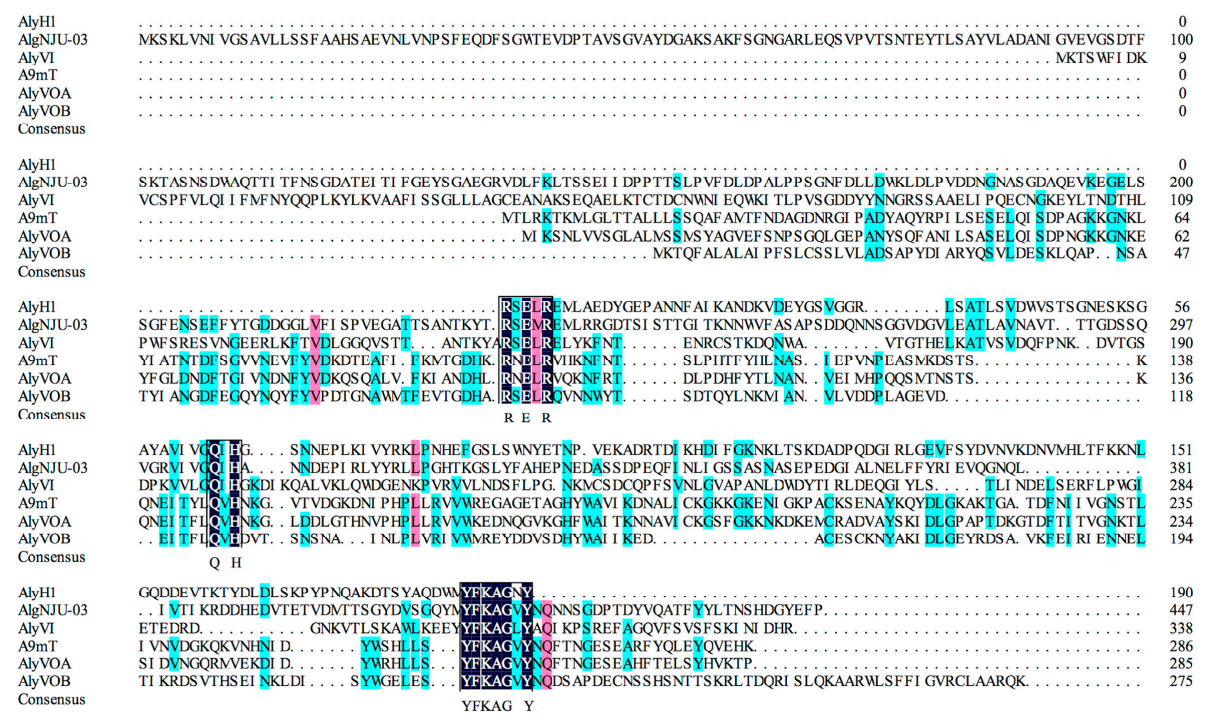

Figure 4. Comparison of the partial amino acid sequence of AlyH1 with alginate lyases AlgNJU-03 from Vibrio sp. NJU-03 (ASA33933.1), AlyVI from Vibrio sp. QY101(AAP45155.1), A9mT from Vibrio sp. JAM-A9m (BAH79131.1), AlyVOA from Vibrio sp. O2 (ABB36771.1), and AlyVOB from Vibrio sp. O2 (ABB36772.1). Identical amino acids are shaded black, whereas similar amino acids are shaded purple or light blue. Conserved regions are boxed. 


\section{Materials and Methods}

\subsection{Microorganism, Media, and Culture Conditions}

The alginate lyase-producing bacterial strain used in this study was isolated from rotten seaweed via an enrichment procedure. Decomposed seaweed samples were collected in Lianyungang City, China. All chemicals were of reagent grade. A selection medium using sodium alginate as the sole carbon source containing $5.0 \mathrm{~g} / \mathrm{L}$ sodium alginate, $5.0 \mathrm{~g} / \mathrm{L}\left(\mathrm{NH}_{4}\right)_{2} \mathrm{SO}_{4}, 2.0 \mathrm{~g} / \mathrm{L} \mathrm{K} \mathrm{HPO}_{4}, 30.0 \mathrm{~g} / \mathrm{L}$ $\mathrm{NaCl}, 1.0 \mathrm{~g} / \mathrm{L} \mathrm{MgSO}_{4} \cdot 7 \mathrm{H}_{2} \mathrm{O}$, and $0.01 \mathrm{~g} / \mathrm{L} \mathrm{FeSO}_{4} \cdot 7 \mathrm{H}_{2} \mathrm{O}$ at $\mathrm{pH} 7.0$ was used for the microorganism isolation. A fermentation medium was composed of $6.0 \mathrm{~g} / \mathrm{L}$ sodium alginate, $5.0 \mathrm{~g} / \mathrm{L}$ tryptone, $2.5 \mathrm{~g} / \mathrm{L}$ yeast extract, $25.0 \mathrm{~g} / \mathrm{L} \mathrm{NaCl}, 0.25 \mathrm{~g} / \mathrm{L} \mathrm{KH}_{2} \mathrm{PO}_{4}, 0.5 \mathrm{~g} / \mathrm{L} \mathrm{MgSO}_{4} \cdot 7 \mathrm{H}_{2} \mathrm{O}$, and $0.05 \mathrm{~g} / \mathrm{L} \mathrm{FeSO} \cdot 7 \mathrm{H}_{2} \mathrm{O}$ at $\mathrm{pH}$ 7.5. Solid medium was prepared by adding $18 \mathrm{~g} / \mathrm{L}$ of agar to the above medium. Microorganisms were aerobically cultured in the $250 \mathrm{~mL}$ shake flasks containing $25 \mathrm{~mL}$ liquid medium at $28^{\circ} \mathrm{C}$ and $150 \mathrm{rpm}$.

\subsection{Strain Isolation and Identification}

The preliminary screening for the alginate-degrading microorganism was conducted as follows. First, $1 \mathrm{~g}$ sample of decomposed seaweed sample was suspended in $10 \mathrm{~mL}$ selection medium. Next, $1 \mathrm{~mL}$ suspension samples were transferred to $25 \mathrm{~mL}$ selection medium for enrichment and were cultivated at $28{ }^{\circ} \mathrm{C}$ for $48 \mathrm{~h}$ with continuous shaking at $150 \mathrm{rpm}$. Microorganisms that could grow in a selection medium were accumulated by subculturing on selection medium plates containing $1.8 \%$ agar for isolation until pure cultures were obtained.

The pure microorganisms were transferred to a new plate and incubated at $28{ }^{\circ} \mathrm{C}$ for $48 \mathrm{~h}$, while original plates were poured with $1 \% \mathrm{CaCl}_{2}$ solution. Strains with clear hydrolytic zones were selected and incubated aerobically in a fermentation medium under the same conditions as above for rescreening high alginate lyase activity strains. Among the isolates, the most active strain, H1, was selected for further studies.

Bacterial identification was performed based on the 16S rRNA gene sequence, which was amplified by PCR using the primers: 27F (5'-AGAGTTTGATCCTGGCTCAG-3') and 1492R ( $5^{\prime}$-GGTTACCTTGTTACGACTT-3'). The PCR product was sequenced by Sangon Biotech (Shanghai, China). The sequence was blasted at NCBI and registered at the GeneBank database. A phylogenetic tree was built using MEGA 5.0 software (Biodesign Institute, Arizona State University, Tempe, AZ, USA) with the neighbour-joining method.

\subsection{Purification of Alginate Lyase}

Enzyme purification was performed by using an AKTA purifier (GE Healthcare, Piscataway, NJ, USA). Sodium phosphate buffer (PB, $50 \mathrm{mM}, \mathrm{pH} 7.5)$ containing $1 \mathrm{mM}$ DTT was used as the standard buffer (Buffer A).

\section{Step 1: Ammonium sulphate fractionation}

The supernatant from one litre of culture supernatant were harvested via centrifugation at $8000 \mathrm{rpm}$ for $20 \mathrm{~min}$. Ammonium sulphate was gradually added to the crude extract with a final concentration of $30 \%$ and the mixture was stirred on ice for $1 \mathrm{~h}$. The precipitate formed was removed by centrifugation $\left(20,000 \times g, 10 \mathrm{~min}\right.$ at $\left.4{ }^{\circ} \mathrm{C}\right)$ and discarded. The clear supernatant obtained was subjected to increased concentration of $75 \%$ ammonium sulphate and the mixture was stirred for an additional hour on ice. The resulting precipitate was collected by centrifugation $(20,000 \times g, 10 \mathrm{~min}$ at $4{ }^{\circ} \mathrm{C}$ ) and dissolved in $40 \mathrm{~mL}$ Buffer A. It was then dialyzed against a large volume of Buffer A.

Step 2: Q-Sepharose chromatography

The crude enzyme solution from Step 1 was filtered through a $0.45 \mu \mathrm{m}$ filter membrane and was then applied to a $5 \mathrm{~mL}$ Q-Sepharose column which had been equilibrated with Buffer A. Elution was 
performed with a linear gradient of $\mathrm{NaCl}(0.2-0.8 \mathrm{M})$ in Buffer A. Fractions containing alginate lyase activity were pooled and concentrated using an Amicon Ultra-4 unit (Millipore, Billerica, MA, USA).

Step 3: Superdex ${ }^{\mathrm{TM}} 200$ gel filtration chromatography

The protein solution obtained after ion exchange chromatography was placed on a gel filtration chromatography, Superdex ${ }^{\mathrm{TM}} 200$ 10/300 GL column, which was pre-equilibrated with Buffer A containing $0.2 \mathrm{M} \mathrm{NaCl}$. The enzyme was eluted with the same buffer, and AlyH1 was collected, dialyzed, and used for further study.

The protein concentration was determined by the Coomassie Brilliant Blue G-250 dye-binding method of Bradford [39] with bovine serum albumin as a standard. The molecular mass of the purified enzyme was analysed by $12.5 \%$ SDS-PAGE. The proteins were developed by Coomassie Brilliant Blue R-250 staining.

\subsection{Alginate Lyase Assay}

Alginate lyase activity was determined by measuring the amount of released reducing sugar using the 3,5-dinitrosalicylic acid (DNS) method following Dou et al. [6] with slight modification. The reaction was initiated by adding $0.1 \mathrm{~mL}$ of the prepared enzyme to $0.9 \mathrm{~mL}$ of $1 \%$ sodium alginate (dissolved in $50 \mathrm{mM} \mathrm{PB}$ at $\mathrm{pH}$ 7.5). After incubation at $40^{\circ} \mathrm{C}$ for $20 \mathrm{~min}$, the reaction was stopped by adding $0.5 \mathrm{~mL}$ of DNS reagent and heating at $100{ }^{\circ} \mathrm{C}$ for $5 \mathrm{~min}$. After cooling to room temperature, the activity was measured by monitoring the increased absorbance of the reaction products (reducing sugar) at $540 \mathrm{~nm}$. One unit of alginate lyase activity (U) was defined as the amount of enzyme required to generate $1 \mathrm{mg}$ of reducing sugar (glucose equivalent) per min. All assays were performed in triplicate.

\subsection{Characterization of AlyH1}

\subsubsection{Effects of Temperature and $\mathrm{pH}$ on AlyH1 Activity and Stability}

The effects of temperature $\left(20-60^{\circ} \mathrm{C}\right)$ on the enzyme were investigated at $\mathrm{pH} 7.5$. The thermal stability of the enzyme was determined under the standard assay conditions after incubating purified enzyme solutions at $20-60^{\circ} \mathrm{C}$ for $30 \mathrm{~min}$. Meanwhile, the effects of $\mathrm{pH}$ on the enzyme activity were evaluated by incubating the purified enzyme in $\mathrm{PB}$ over the $\mathrm{pH}$ ranges of 6.0 to 9.5 . The $\mathrm{pH}$ stability depended on the residual enzyme activity when the enzyme was conserved in different $\mathrm{pH}$ at $4{ }^{\circ} \mathrm{C}$ for $12 \mathrm{~h}$ in advance.

\subsubsection{Effects of $\mathrm{NaCl}$ Concentration and Metal Ions on AlyH1 Activity}

The effects of $\mathrm{NaCl}$ on alginate lyase activity were investigated at different concentrations between 0-0.6 $\mathrm{M}$ under standard test conditions. The influences of different metal ions on the enzyme activity were performed by incubating the enzyme in $50 \mathrm{mM} \mathrm{PB} \mathrm{(pH} \mathrm{7.5)} \mathrm{at} 4{ }^{\circ} \mathrm{C}$ for $30 \mathrm{~min}$ in the presence of various metal compounds at a concentration of $5 \mathrm{mM}$. Further residual activities were then assayed.

\subsubsection{Kinetic Parameters}

The kinetic constants of the purified enzyme were determined by measuring activity at different sodium alginate concentrations. The maximal reaction rate $(V \max )$ and apparent Michaelis-Menten constant $(\mathrm{Km})$ were determined by linear regression analysis of the Lineweaver-Burke double-reciprocal plot [40].

\subsubsection{Substrate Specificity}

To investigate the substrate specificity, $1 \%$ sodium alginate, poly-M, and poly-G were used as the substrates to determine the enzyme activity. Poly-M and poly-G were prepared via HCl-hydrolysis according to the procedure described by Gong et al. [32]. Briefly, sodium alginate (1.0 g) was dissolved 
in $50 \mathrm{~mL}$ of $1 \mathrm{M} \mathrm{HCl}$ and kept in a water bath at $90{ }^{\circ} \mathrm{C}$ for $5 \mathrm{~h}$. The solution was then cooled and centrifuged at $8000 \times g$ for $20 \mathrm{~min}$. The sediment was suspended in deionized water and adjusted to neutral $\mathrm{pH}$ until dissolved fully using $\mathrm{NaOH}$ solution. Then it was adjusted to a $\mathrm{pH}$ of 2.86 with $\mathrm{HCl}$. After being centrifuged at $8000 \times g$ for $20 \mathrm{~min}$, the insoluble part (which is poly-G) was dissolved, dialyzed, and freeze-dried. Next, the supernatant was adjusted to a $\mathrm{pH}$ of 1.0. After being centrifuged at $8000 \times g$ for $20 \mathrm{~min}$, the poly-G precipitate was dissolved, dialyzed, and freeze-dried. The assay of enzyme activity was the same as previously described.

\subsubsection{TLC Analysis of the Degradation Products}

Thin-layer chromatography (TLC) was applied to analyse the oligosaccharides produced by the degradation of sodium alginate with the purified AlyH1. The reaction mixture containing $1 \mathrm{~mL}$ of $1.0 \%$ sodium alginate and $1 \mathrm{~mL}$ of enzyme was incubated at $30^{\circ} \mathrm{C}$ for $24 \mathrm{~h}$. A $5 \mu \mathrm{L}$ aliquot of the reaction product was subjected to TLC using a solvent system of 1-butanol: acetic acid: water (3:2:2, v/v). The plate was then sprayed with $10 \%(v / v)$ sulfuric acid in ethanol and heated at $120{ }^{\circ} \mathrm{C}$ for $5 \mathrm{~min}[41]$.

\subsubsection{Determination of Partial Amino Acid Sequences of AlyH1}

The identification of the internal peptide sequence of AlyH1 was carried out through mass spectrometry. The purified protein in SDS-PAGE was cut out. After destaining (100 $\mathrm{mM} \mathrm{NH}_{4} \mathrm{HCO}_{3}$ and $30 \%$ acetonitrile) and washing, the dried gel pieces were treated with trypsin $(50 \mu \mathrm{g} / \mathrm{mL}) \mathrm{in}$ $50 \mathrm{mM} \mathrm{NH}{ }_{4} \mathrm{HCO}_{3}$ buffer ( $\mathrm{pH} 8.0$ ) at $37^{\circ} \mathrm{C}$ overnight. Considering the different molecular masses with different time-of-flight detections, these peptide fragments were analysed using an Applied Biosystem reflectron time-of-flight mass spectrometer and identified by comparison with various protein identification databases. Degenerate primers Valg1 (5-CGBTCDGARCTBCGBGMRATG-3) and Valg2 (5-RTARTTRCCBGCYTTRAARTA-3) were designed according to the conserved regions R(S/N) $\operatorname{ELR}(\mathrm{E} / \mathrm{A} / \mathrm{V})(\mathrm{M} / \mathrm{T} / \mathrm{Q})$ and YFKAG(N/L/A/V) Y of the PL7 alginate lyases [38] to amplify the partial sequence of the alyH1 using the genomic DNA of $\mathrm{H} 1$ as a template. Amplified fragments were purified and ligated with pMD19-T plasmid by T/A cloning, and transformed into E. coli JM109 competent cells. Finally, positive clone was sequenced by Sangon Biotech (Shanghai, China). The deduced amino sequence was analysed using DNAMAN software (Lynnon biosoft, San Ramon, CA, USA) and the BLAST tool of NCBI.

\section{Conclusions}

In this study, a new alginate lyase-producing marine bacterium was isolated and identified as V. furnissii H1. AlyH1 secreted by V. furnissii $\mathrm{H} 1$ was characterized as a novel PL7 alginate lyase. The enzyme showed excellent characteristics, such as a broad $\mathrm{pH}$ range for enzyme activity, thermal stability, and specificity for both poly-M and poly-G, and could hydrolyse alginate to produce low polymerization oligosaccharides. These characteristics indicate that AlyH1 may play a role in marine alginate degradation and carbon cycling and open potential applications for large-scale industrialization. Further works will be focused on obtaining the full length and heterologous expression of AlyH1 to further elucidate the function of the enzyme, and lay a better foundation for its practical application.

Supplementary Materials: The following are available online at www.mdpi.com/1660-3397/16/1/30/s1. Figure S1. Phylogenetic tree for strain H1 and related strains based on the 16S rRNA gene sequence. Numbers after the names of organisms are the accession numbers of the published sequences. The phylogenetic tree was inferred by using the neighbour-joining methods. The software MEGA 5.0 was used for analysis. Figure S2. Effects of $\mathrm{NaCl}$ concentration and metal ions on the activity of AlyH1. (a) Influences of the concentration of $\mathrm{NaCl}$; (b) Influences of the metal ions. The enzyme activity without metal ions served as the control with the corresponding enzyme activity designated as 100\%. Figure S3. Partial nucleotide sequence of the alyH1.

Acknowledgments: The authors gratefully acknowledge the financial support of the National Natural Science Foundation of China (No. 21706089), the National Natural Science Foundation of China (No. 21576110), the Huaian Key Research and Development Project (No. HAN2015026), the Jiangsu Province Science and Technology Plan 
(BY2016061-05), the Opening Fund of the Jiangsu Provincial Engineering Laboratory for Biomass Conversion and Process Integration (Huaiyin Institute of Technology) (No. JPELBCPL2013009), and the Opening Fund of the Jiangsu Key Laboratory for Biomass-based Energy and Enzyme Technology (Huaiyin Normal University) (No. JSBEET1304). I received funds for covering the costs to publish in open access.

Author Contributions: X.Z. and X.Li. conceived and designed the experiments; M.Y. and P.Y. performed the experiments; X.Z., H.S., and J.Z. analyzed the data; Z.T. and X.Liu. contributed reagents/materials/analysis tools; and X.Z. wrote the paper. All authors reviewed the manuscript.

Conflicts of Interest: The authors declare no conflict of interest.

\section{References}

1. Ravanal, M.C.; Sharma, S.; Gimpel, J.; Reveco-Urzua, F.E.; Øverland, M.; Horn, S.J.; Lienqueo, M.E. The role of alginate lyases in the enzymatic saccharification of brown macroalgae, Macrocystis pyrifera and Saccharina latissima. Algal Res. 2017, 26, 287-293. [CrossRef]

2. Kim, H.S.; Lee, C.G.; Lee, E.Y. Alginate lyase: Structure, property, and application. Biotechnol. Bioprocess Eng. 2011, 16, 843-851. [CrossRef]

3. Wargacki, A.J.; Leonard, E.; Win, M.N.; Regitsky, D.D.; Santos, C.N.; Kim, P.B.; Cooper, S.R.; Raisner, R.M.; Herman, A.; Sivitz, A.B.; et al. An engineered microbial platform for direct biofuel production from brown macroalgae. Science 2012, 335, 308-313. [CrossRef] [PubMed]

4. Boucelkha, A.; Petit, E.; Elboutachfaiti, R.; Molinié, R.; Amari, S.; Yahaoui, R.Z. Production of guluronate oligosaccharide of alginate from brown algae Stypocaulon scoparium using an alginate lyase. J. Appl. Phycol. 2016, 29, 509-519. [CrossRef]

5. Zhu, B.; Yin, H. Alginate lyase: Review of major sources and classification, properties, structure-function analysis and applications. Bioengineered 2015, 6, 125-131. [CrossRef] [PubMed]

6. Dou, W.; Wei, D.; Li, H.; Li, H.; Rahman, M.M.; Shi, J.; Xu, Z.; Ma, Y. Purification and characterisation of a bifunctional alginate lyase from novel Isoptericola halotolerans CGMCC 5336. Carbohydr. Polym. 2013, 98, 1476-1482. [CrossRef] [PubMed]

7. Iwamoto, Y.; Araki, R.; Iriyama, K.I.; Oda, T.; Fukuda, H.; Hayashida, S.; Muramatsu, T. Purification and characterization of bifunctional alginate lyase from Alteromonas sp. strain No. 272 and its action on saturated oligomeric substrates. Biosci. Biotechnol. Biochem. 2001, 65, 133-142. [CrossRef] [PubMed]

8. Lombard, V.; Bernard, T.; Rancurel, C.; Brumer, H.; Coutinho, P.M.; Henrissat, B. A hierarchical classification of polysaccharide lyases for glycogenomics. Biochem. J. 2010, 432, 437-444. [CrossRef] [PubMed]

9. Chen, J.; Hu, Y.; Zhang, L.; Wang, Y.; Wang, S.; Zhang, Y.; Guo, H.; Ji, D.; Wang, Y. Alginate oligosaccharide DP5 exhibits antitumor effects in osteosarcoma patients following surgery. Front. Pharmacol. 2017, 8. [CrossRef] [PubMed]

10. Wang, X.; Wang, L.; Che, J.; Li, X.; Li, J.; Wang, J.; Xu, Y. In vitro non-specific immunostimulatory effect of alginate oligosaccharides with different molecular weights and compositions on sea cucumber (Apostichopus japonicus) coelomocytes. Aquaculture 2014, 434, 434-441. [CrossRef]

11. Falkeborg, M.; Cheong, L.Z.; Gianfico, C.; Sztukiel, K.M.; Kristensen, K.; Glasius, M.; Xu, X.; Guo, Z. Alginate oligosaccharides: Enzymatic preparation and antioxidant property evaluation. Food Chem. 2014, 164, 185-194. [CrossRef] [PubMed]

12. Iwasaki, K.I.; Matsubara, Y. Purification of alginate oligosaccharides with root growth-promoting activity toward lettuce. Biosci. Biotechnol. Biochem. 2000, 64, 1067-1070. [CrossRef] [PubMed]

13. Aarstad, O.A.; Tøndervik, A.; Sletta, H.; Skjåk-Bræk, G. Alginate sequencing: An analysis of block distribution in alginates using specific alginate degrading enzymes. Biomacromolecules 2012, 13, 106-116. [CrossRef] [PubMed]

14. Inoue, A.; Mashino, C.; Kodama, T.; Ojima, T. Protoplast preparation from Laminaria japonica with recombinant alginate lyase and cellulase. Mar. Biotechnol. 2011, 13, 256-263. [CrossRef] [PubMed]

15. Islan, G.A.; Bosio, V.E.; Castro, G.R. Alginate lyase and ciprofloxacin co-immobilization on biopolymeric microspheres for cystic fibrosis treatment. Macromol. Biosci. 2013, 13, 1238-1248. [CrossRef] [PubMed]

16. Zhu, Y.; Wu, L.; Chen, Y.; Ni, H.; Xiao, A.; Cai, H. Characterization of an extracellular biofunctional alginate lyase from marine Microbulbifer sp. ALW1 and antioxidant activity of enzymatic hydrolysates. Microbiol. Res. 2016, 182, 49-58. [CrossRef] [PubMed] 
17. Li, S.; Wang, L.; Hao, J.; Xing, M.; Sun, J.; Sun, M. Purification and characterization of a new aginate lyase from marine bacterium Vibrio sp. SY08. Mar. Drugs 2017, 15, 1. [CrossRef] [PubMed]

18. Chao, Y.; Wang, S.; Wu, S.; Wei, J.; Chen, H. Cloning and characterization of an alginate lyase from marine Vibrio. sp. QD-5. Preprints 2017, 2017050055. [CrossRef]

19. Zhu, B.; Sun, Y.; Ni, F.; Ning, L.; Yao, Z. Characterization of a new endo-type alginate lyase from Vibrio sp. NJU-03. Int. J. Biol. Macromol. 2017, in press. [CrossRef] [PubMed]

20. Zhu, B.; Tan, H.; Qin, Y.; Xu, Q.; Du, Y.; Yin, H. Characterization of a new endo-type alginate lyase from Vibrio sp. W13. Int. J. Biol. Macromol. 2015, 75, 330-337. [CrossRef] [PubMed]

21. Badur, A.H.; Jagtap, S.S.; Yalamanchili, G.; Lee, J.K.; Zhao, H.; Rao, C.V. Alginate lyases from alginate-degrading Vibrio splendidus 12B01 are endolytic. Appl. Environ. Microbiol. 2015, 81, 1865-1873. [CrossRef] [PubMed]

22. Jagtap, S.S.; Hehemann, J.H.; Polz, M.F.; Lee, J.K.; Zhao, H. Comparative biochemical characterization of three exolytic oligoalginate lyases from Vibrio splendidus reveals complementary substrate scope, temperature, and $\mathrm{pH}$ adaptations. Appl. Environ. Microbiol. 2014, 80, 4207-4214. [CrossRef] [PubMed]

23. Uchimura, K.; Miyazaki, M.; Nogi, Y.; Kobayashi, T.; Horikoshi, K. Cloning and sequencing of alginate lyase genes from deep-sea strains of Vibrio and Agarivorans and characterization of a new Vibrio enzyme. Mar. Biotechnol. 2010, 12, 526-533. [CrossRef] [PubMed]

24. Wang, Y.; Guo, E.W.; Yu, W.G.; Han, F. Purification and characterization of a new alginate lyase from a marine bacterium Vibrio sp. Biotechnol. Lett. 2013, 35, 703-708. [CrossRef] [PubMed]

25. Fu, X.T.; Lin, H.; Kim, S.M. Purification and characterization of a $\mathrm{Na}^{+} / \mathrm{K}^{+}$dependent alginate lyase from turban shell gut Vibrio sp. YKW-34. Enzym. Microb. Technol. 2007, 41, 828-834. [CrossRef]

26. Wang, Y.H.; Yu, G.L.; Wang, X.M.; Lv, Z.H.; Zhao, X.; Wu, Z.H.; Ji, W.S. Purification and characterization of alginate lyase from marine Vibrio sp. YWA. Acta Biochim. Biophys. Sin. 2006, 38, 633-638. [CrossRef] [PubMed]

27. Kawamoto, H.; Horibe, A.; Miki, Y.; Kimura, T.; Tanaka, K.; Nakagawa, T.; Kawamukai, M.; Matsuda, H. Cloning and sequencing analysis of alginate lyase genes from the marine bacterium Vibrio sp. O2. Mar. Biotechnol. 2006, 8, 481-490. [CrossRef] [PubMed]

28. Hu, X.; Jiang, X.; Hwang, H.M. Purification and Characterization of an Alginate Lyase from Marine Bacterium Vibrio sp. Mutant Strain 510-64. Curr. Microbiol. 2006, 53, 135-140. [CrossRef] [PubMed]

29. Han, F.; Gong, Q.H.; Song, K.; Li, J.B.; Yu, W.G. Cloning, sequence analysis and expression of gene alyVI encoding alginate lyase from marine bacterium Vibrio sp. QY101. DNA Seq. 2004, 15, 344-350. [CrossRef] [PubMed]

30. Tseng, C.H.; Yamaguchi, K.; Kitamikado, M. Isolation and some properties of alginate lyase from a marine bacterium Vibrio sp. AL-128. Nippon Suisan Gakkaishi 1992, 58, 533-538. [CrossRef]

31. Tseng, C.H.; Yamaguchi, K.; Kitamikado, M. Two types of alginate lyase from a marine bacterium Vibrio sp. AL-9. Nippon Suisan Gakkaishi 1992, 58, 743-749. [CrossRef]

32. Gong, J.S.; Liu, X.M.; Zhang, M.J.; Li, H.; Geng, Y.; Li, H.; Li, J.; Lu, Z.M.; Xu, Z.H.; Shi, J.S. Purification and characterization of a high salt-tolerant alginate lyase from Cobetia sp. WG-007. Biotechnol. Appl. Biochem. 2017, 64, 519-524. [CrossRef] [PubMed]

33. Li, J.W.; Dong, S.; Song, J.; Li, C.B.; Chen, X.L.; Xie, B.B.; Zhang, Y.Z. Purification and characterization of a bifunctional alginate lyase from Pseudoalteromonas sp. SM0524. Mar. Drugs 2011, 9, 109-123. [CrossRef] [PubMed]

34. Singh, R.P.; Gupta, V.; Kumari, P.; Kumar, M.; Reddy, C.R.K.; Prasad, K.; Jha, B. Purification and partial characterization of an extracellular alginate lyase from Aspergillus oryzae isolated from brown seaweed. J. Appl. Phycol. 2011, 23, 755-762. [CrossRef]

35. Kobayashi, T.; Uchimura, K.; Miyazaki, M.; Nogi, Y.; Horikoshi, K. A new high-alkaline alginate lyase from a deep-sea bacterium Agarivorans sp. Extremophiles 2009, 13, 121-129. [CrossRef] [PubMed]

36. Swift, S.M.; Hudgens, J.W.; Heselpoth, R.D.; Bales, P.M.; Nelson, D.C. Characterization of AlgMsp, an alginate lyase from Microbulbifer sp. 6532A. PLoS ONE 2014, 9, e112939. [CrossRef] [PubMed]

37. Sim, S.J.; Baik, K.S.; Park, S.C.; Choe, H.N.; Seong, C.N.; Shin, T.S.; Woo, H.C.; Cho, J.Y.; Kim, D. Characterization of alginate lyase gene using a metagenomic library constructed from the gut microflora of abalone. J. Ind. Microbiol. Biotechnol. 2012, 39, 585-593. [CrossRef] [PubMed] 
38. Yamasaki, M.; Ogura, K.; Hashimoto, W.; Mikami, B.; Murata, K. A structural basis for depolymerization of alginate by polysaccharide lyase family-7. J. Mol. Biol. 2005, 352, 11-21. [CrossRef] [PubMed]

39. Bradford, M.M. A rapid and sensitive method for the quantitation of microgram quantities of protein utilizing the principle of protein-dye binding. Anal. Biochem. 1976, 72, 248-254. [CrossRef]

40. Lineweaver, H.; Burk, D. The determination of enzyme dissociation constants. J. Am. Chem. Soc. 1934, 56, 658-666. [CrossRef]

41. Ma, L.Y.; Chi, Z.M.; Li, J.; Wu, L.F. Overexpression of alginate lyase of Pseudoalteromonas elyakovii in Escherichia coli, purification, and characterization of the recombinant alginate lyase. World J. Microbiol. Biotechnol. 2008, 24, 89-96. [CrossRef]

(C) 2018 by the authors. Licensee MDPI, Basel, Switzerland. This article is an open access article distributed under the terms and conditions of the Creative Commons Attribution (CC BY) license (http:/ / creativecommons.org/licenses/by/4.0/). 